\title{
PENDAPATAN USAHATANI BAYAM DI DESA CIARUTEUN ILIR KECAMATAN CIBUNGBULANG KABUPATEN BOGOR JAWA BARAT
}

\author{
Pratica Dewi ${ }^{1)}$, dan Anna Fariyanti ${ }^{2)}$ \\ ${ }^{1,2)}$ Departemen Agribisnis, Fakultas Ekonomi dan Manajemen, Institut Pertanian Bogor \\ ${ }^{1)}$ caca.darsono@gmail.com
}

\begin{abstract}
Spinach as an economic crop is known as the king of vegetables and loved by the whole society. The purpose of this research was to analyze spinach farm income, level offarm efficiency, return to labor and return to capital. The data were analyzed using descriptive statistic methods, farm income analysis, and $R / C$ ratio using a sample of 30 large-scale farmers and 30 small-scale farmers. The result showed that the income of large-scale farmers were greater than that of small-scale farmers in dry (September-October 2013) and rainy (February-March 2014) cropping season. Meanwhile, the income of small-scale and large-scale farmers in the rainy season was higher than in the dry season because of the high price of spinach. $R / C$ ratio of spinach farming was greater than one. The $R / C$ ratio indicated that spinach farming was efficient. Based on the return to labor and return to capital, it can be concluded that the farmers'decision to grow spinach in Ciaruteun Ilir Village was right. Farmers should be responsive to the growing season and the creation of value-added spinach, and the plastic hood should be made to protect the spinach plants from pests and diseases.
\end{abstract}

Keyword(s): farm income analysis, $R / C$ ratio analysis, spinach

\begin{abstract}
ABSTRAK
Bayam sebagai tanaman ekonomi dikenal sebagai King of Vegetables dan digemari oleh seluruh lapisan masyarakat. Tujuan penelitian ini adalah menganalisis tingkat pendapatan usahatani bayam, tingkat efisiensi usahatani, imbalan terhadap tenaga kerja dan imbalan terhadap modal. Data dianalisis menggunakan metode deskriptif statistik, analisis pendapatan usahatani, dan R/C rasio dengan menggunakan sampel sebanyak 30 orang petani lahan luas dan 30 orang petani lahan sempit. Hasil menunjukkan bahwa pendapatan petani lahan luas lebih tinggi daripada petani lahan sempit baik pada musim kemarau (September-Oktober 2013) maupun musim hujan (Februari-Maret 2014). Sementara itu, pendapatan petani lahan sempit dan petani lahan luas pada musim hujan lebih tinggi dibandingkan musim kemarau karena harga jual bayam yang tinggi. $\mathrm{R} / \mathrm{C}$ rasio dari usahatani bayam besar dari satu. Nilai $\mathrm{R} / \mathrm{C}$ rasio tersebut mengindikasikan bahwa usahatani bayam efisien untuk dilakukan. Berdasarkan hasil imbalan terhadap tenaga kerja dan modal dapat disimpulkan bahwa pilihan petani untuk melakukan usahatani bayam di Desa Ciaruteun Ilir sudah tepat. Petani sebaiknya responsif terhadap musim tanam, penciptaan nilai tambah bayam, dan membuat tudung plastik untuk melindungi tanaman bayam dari serangan hama dan penyakit.
\end{abstract}

Kata Kunci: analisis pendapatan usahatani, analisis R/C rasio, bayam 


\section{PENDAHULUAN}

Pembangunan hortikultura telah memberikan sumbangan yang berarti bagi sektor pertanian maupun perekonomian nasional yang dapat dilihat dari nilai Produk Domestik Bruto (PDB), jumlah rumah tangga yang mengandalkan sumber pendapatan dari sub sektor hortikultura, penyerapan tenaga kerja, dan peningkatan pendapatan masyarakat (Direktorat Jenderal Hortikultura 2012). Keadaan ekonomi yang semakin membaik menjadikan konsumsi beras semakin berkurang digantikan sayur, buah, daging, dan telur.

Pardede (2013) menyatakan bahwa keuntungan bertanam hortikultura diantaranya pendapatan setiap satuan luas lahan bisa mencapai 120 kali bertanam padi. Kondisi di Indonesia, padi dengan luas panen 13.4 juta hektar memberikan kontribusi terhadap PDB sebesar 2.5 persen, sedangkan hortikultura dengan luas panen 1.8 juta hektar memberikan kontribusi terhadap PDB sebesar 1.5 persen.

Masyarakat Indonesia umumnya menyukai sayuran sebagai menu makanan sehari-hari karena sayuran mengandung gizi dan serat yang diperlukan tubuh. Sayuran merupakan sumber makanan yang penting dan dibudidayakan secara luas (AdebisiAdeani et al. 2011). Komoditas sayuran yang mendapat julukan sebagai "King of Vegetables" adalah sayuran bayam karena memiliki nilai gizi yang lebih tinggi dibandingkan sayuran lainnya (Rukmana 1994). Bayam sudah lama digemari oleh seluruh lapisan masyarakat dan merupakan sayuran penyangga dalam penghasilan rumah tangga petani di Indonesia (Hadisoeganda 1996). Selain itu, terdapat peluang yang cukup besar pada produksi bayam jika sumberdaya digunakan secara efisien (Abu dan Asember 2011). Produk turunan bayampun beraneka-ragam dan banyak dimanfaatkan sebagai makanan berenergi tinggi.

Peningkatan laju pertumbuhan penduduk dan pemenuhan akan kebutuhan pangan yang bergizi, menjadikan bayam sebagai salah satu komoditi sayuran yang dapat diandalkan bagi pemenuhan kebutuhan vitamin dan mineral yang relatif mudah dan murah. Namun demikian, tanaman bayam yang mempunyai prospek sebagai tanaman sumber vitamin dan mineral yang andal, belum diusahakan dalam skala luas. Luas panen, produksi, dan produktivitas bayam di Indonesia pada dua tahun terakhir mengalami penurunan dengan masingmasing sebesar 1.43 persen, 3.39 persen, dan 1.99 persen (Badan Pusat Statistik 2013). Penurunan luas panen, produksi, dan produktivitas bayam ini berbanding terbalik dengan harga bayam yang berlaku di Indonesia yang mengalami peningkatan dari tahun ke tahun. Hal ini ditunjukkan oleh perkembangan rata-rata harga produsen dan konsumen bayam.

Rata-rata harga produsen dan konsumen bayam terus meningkat, masingmasing mengalami pertumbuhan sebesar 10.77 persen dan 13.68 persen (Badan Pusat Statistik 2013). Peningkatan harga khususnya harga produsen mengindikasikan bahwa terjadi kenaikan harga yang dibayarkan pedagang pengumpul kepada petani. Hal ini secara tidak langsung 
memberikan potensi terhadap peningkatan penerimaan petani, sehingga dibutuhkan analisis pendapatan petani untuk mengetahui tingkat pendapatan yang diperoleh petani dari fakta penurunan produksi bayam dan kenaikan harga bayam di pasar.

Provinsi Jawa Barat merupakan salah satu daerah utama penghasil bayam karena memiliki iklim, tekstur tanah, dan cuaca yang cocok dengan komoditas sayuran ini. Salah satu sentra penghasil bayam di Jawa Barat adalah Kabupaten Bogor (Dinas Pertanian Tanaman Pangan Provinsi Jawa Barat 2012). Salah satu daerah produksi komoditas bayam di Kabupaten Bogor adalah Kecamatan Cibungbulang, tepatnya Desa Ciaruteun Ilir. Desa ini memiliki potensi yang besar dalam produksi sayuran bayam karena hampir 90 persen penduduknya bekerja sebagai petani bayam (Pemerintah Desa Ciaruteun Ilir 2013). Dilihat dari segi pendapatan petani, masih dijumpai berbagai permasalahan. Permasalahan yang terjadi diantaranya yaitu luasan lahan pertanian yang mampu digarap petani. Mayoritas petani mengusahakan sayuran bayam dalam skala usaha yang kecil dan terpencar-pencar (kurang dari 0.25 hektar). Luas lahan yang digarap petani akan berpengaruh terhadap besar kecilnya pendapatan yang akan diterima petani. Penerimaan petani lahan luas di Desa Ciaruteun Ilir lebih tinggi dibandingkan petani lahan sempit karena memiliki pekerjaan rangkap sebagai pedagang pengumpul yang langsung menjual hasil pertanian ke pasar. Penyebab lain yang menimbulkan adanya keterbatasan pendapatan yang diterima petani yaitu faktor cuaca yang tidak menentu (kondisi antar musim tanam).

Pendapatan petani bayam lebih tinggi pada musim hujan dibandingkan musim kemarau. Hal ini sesuai dengan penelitian yang dilakukan oleh Aldila (2013) yang menunjukkan bahwa pendapatan petani pada musim hujan lebih tinggi daripada musim kemarau karena adanya pengaruh risiko musim tanam. Adanya serangan hama dan penyakit yang tinggi menyebabkan petani harus semakin banyak mengeluarkan biaya untuk membeli obat dan pestisida serta mengalokasikan tenaga kerja dalam hal perawatan tanaman bayam.

Petani sebaiknya memperoleh rasio yang cukup besar antara pendapatan usahatani dibandingkan dengan total biaya produksi karena semakin besar rasio tersebut maka semakin tepatlah pemilihan dalam menggunakan sumberdaya pada usahatani yang dilakukan para petani. Selain itu apabila petani menerima imbalan terhadap faktor produksi usahatani bayam seperti modal dan tenaga kerja yang lebih tinggi daripada biaya imbangannya maka pilihan petani untuk melakukan usahatani bayam sudah tepat. Pertanyaannya apakah usahatani bayam di Desa Ciaruteun Ilir sudah menguntungkan pada usahatani lahan sempit maupun lahan luas pada musim kemarau dan musim hujan? Apakah usahatani sayuran bayam sudah efisien dari segi biaya? Bagaimana imbalan bagi faktorfaktor produksi terutama tenaga kerja dan modal di Desa Ciaruteun Ilir? Berdasarkan uraian tersebut, maka kajian pendapatan usahatani bayam penting dilakukan untuk menjawab pertanyaan tersebut. 
Oleh karena itu, penelitian ini bertujuan untuk menganalisis pendapatan usahatani bayam di Desa Ciaruteun Ilir berdasarkan kondisi antar musim yaitu musim kemarau dan musim penghujan pada usahatani sempit dan usahatani luas, menganalisis tingkat efisiensi biaya serta imbalan tenaga kerja (return to labor) dan imbalan modal (return to capital) pada usahatani bayam.

\section{KERANGKA PEMIKIRAN Fungsi Produksi}

Fungsi produksi merupakan hubungan fisik antara masukan dan produksi. Masukan seperti lahan, pupuk, modal, tenaga kerja, dan sebagainya mempengaruhi besar-kecilnya produksi yang diperoleh (Soekartawi 2002).
Fungsi produksi dapat dinyatakan secara matematis maupun dengan kurva produksi. Gambar 1 merupakan kurva produksi yang menggambarkan hubungan fisik faktor produksi dan hasil produksinya, dengan asumsi hanya satu produksi yang berubah dan faktor produksi lainnya dianggap tetap (cateris paribus). Kurva produksi pada Gambar 1 mencakup produk total, produk rata-rata, dan produk marjinal. Produk total (TP) adalah jumlah total yang diproduksi selama periode waktu tertentu. Produk marjinal (MP) adalah perubahan dalam produk total sebagai akibat penambahan penggunaan input variabel sebanyak satu unit (Lipsey et al. 1995).

Kurva produk total pada saat penggunaan input sebesar 0 sampai

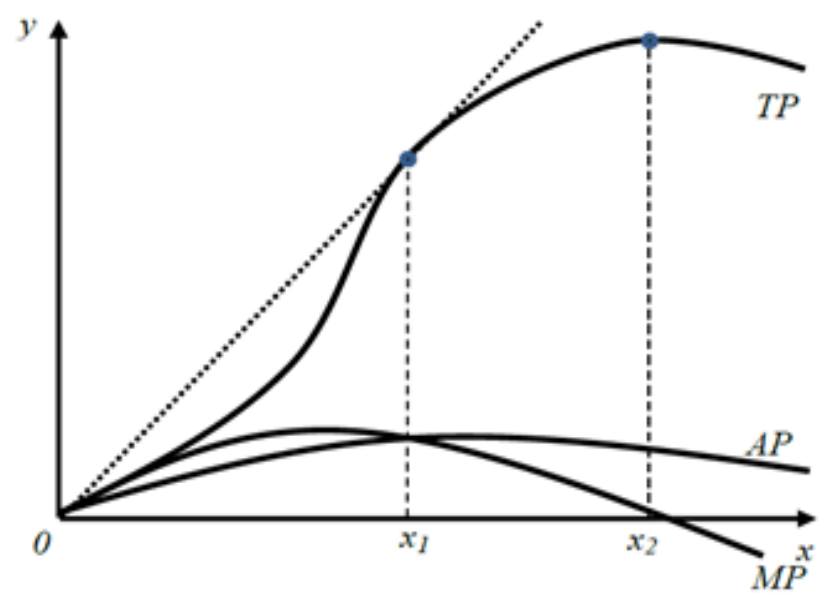

$\begin{array}{ll}\text { Keterangan : } \\ T P= & \text { Produk total } \\ A P= & \text { Produk rata-rata } \\ M P= & \text { Produk marjinal } \\ Y= & \text { Output } \\ X= & \text { Input }\end{array}$

Sumber : Lipsey et al. (1995)

Gambar 1. Kurva Produk Total, Produk Rata-Rata, dan Produk Marjinal 
dengan $x_{1}$ akan meningkat dengan laju peningkatan yang meningkat, dimana penggunaan input sebesar $x_{1}$ akan menyebabkan produktivitas rata-rata optimum. Sementara itu, kurva produk total pada saat penggunaan input sebesar $x_{1}$ sampai dengan $x_{2}$ juga akan meningkat tetapi laju peningkatannya semakin menurun. Kemudian penggunaan input yang lebih besar dari $x_{2}$ justru akan menyebabkan kurva produk total menurun sehingga produk marjinal bernilai negatif. Oleh karena itu, penggunaan input yang akan menghasilkan produksi optimum adalah sebesar antara $x_{1}$ dan $x_{2}$, dimana jumlah penggunaan input sebesar $x_{2}$ akan menghasilkan produksi yang maksimum.

\section{Pengertian Usahatani}

Usahatani menurut Soekartawi (2002) merupakan ilmu yang mempelajari bagaimana cara-cara petani memperoleh dan mengkombinasikan sumberdaya (lahan, tenaga kerja, modal, waktu, dan pengolahan) yang terbatas untuk mencapai tujuannya. Tujuan berusahatani adalah untuk: 1) memaksimumkan keuntungan, dan 2) meminimalkan pengeluaran (Soekartawi 2005). Suratiyah (2009) mengemukakan bahwa terdapat unsur-unsur pokok yang selalu ada pada suatu usahatani yaitu alam, tenaga kerja, modal, dan pengelolaan (manajemen).

\section{Konsep Pendapatan Usahatani}

Anggaran arus uang tunai pada kegiatan usahatani mencakup penerimaan usahatani, biaya, dan pendapatan usahatani. Pendapatan usahatani merupakan imbalan bagi faktor produksi yang didapat dari hasil pengurangan antara penerimaan total dari kegiatan usahatani dengan biaya usahatani. Jumlah pendapatan ini sangat tergantung pada besarnya penerimaan dan biaya usahatani tersebut dalam jangka waktu tertentu.

Analisis pendapatan usahatani dilakukan untuk mengetahui keberhasilan usahatani dilihat dari pendapatan yang diterima. Pendapatan yang semakin besar mencerminkan keberhasilan petani yang semakin baik. Oleh karena itu petani dapat melakukan perencanaan kegiatan usahatani yang lebih baik di masa yang akan datang dengan melakukan analisis tersebut.

Pendapatan yang besar tidak selalu menunjukkan efisiensi yang tinggi. Oleh karena itu, analisis pendapatan selalu diikuti dengan pengukuran efisiensi. Salah satu ukuran efisiensi adalah penerimaan untuk rupiah yang dikorbankan (Revenue Cost Ratio atau R/C Ratio). Hasil analisis $\mathrm{R} / \mathrm{C}$ rasio akan menunjukkan besar penerimaan usahatani yang diperoleh petani untuk setiap satuan biaya yang dikeluarkan dalam kegiatan usahatani. Dilihat dari rasio, semakin besar nilai rasio maka kegiatan usahatani akan semakin efisien. Hal ini dikarenakan dalam unit biaya yang sama, suatu kegiatan usahatani mampu memperoleh penerimaan yang lebih besar.

\section{Konsep Biaya Usahatani}

Biaya usahatani merupakan semua biaya yang dipergunakan dalam suatu usahatani (Soekartawi 2002). Konsep biaya usahatani lebih mengkaji aspekaspek biaya produksi. Biaya produksi 
dalam usahatani dapat dibedakan dalam beberapa bagian :

a. Berdasarkan jumlah output yang dihasilkan, terdiri dari : 1) biaya tetap (biaya yang besar kecilnya tidak tergantung pada besar kecilnya produksi, seperti pajak tanah, sewa tanah, bunga pinjaman, dan penyusutan alatalat pertanian); dan 2) biaya variabel (biaya yang jumlahnya selalu berubah dan besarnya berhubungan langsung dengan jumlah produksi, misalnya pengeluaran untuk benih/bibit, pupuk, dan biaya pekerja).

b. Berdasarkan biaya yang langsung dikeluarkan dan langsung diperhitungkan, terdiri dari : 1) biaya tunai. Biaya ini terbagi menjadi biaya tetap (seperti: pajak tanah dan bunga pinjaman) dan biaya variabel (seperti: pengeluaran untuk benih, pupuk, pestisida, dan tenaga kerja luar keluarga). Selanjutnya, 2) biaya tidak tunai/ diperhitungkan. Biaya ini terbagi menjadi biaya tetap (seperti: biaya penyusutan alat-alat pertanian dan sewa lahan milik sendiri) dan biaya variabel (seperti: tenaga kerja dalam keluarga).

\section{Konsep Imbangan Penerimaan dan Biaya ( $R / C$ rasio)}

Analisis imbangan penerimaan dan biaya $(\mathrm{R} / \mathrm{C}$ rasio) merupakan salah satu metode yang dapat digunakan untuk menilai efisiensi usahatani. $\mathrm{R} / \mathrm{C}$ rasio menunjukkan besarnya penerimaan usahatani yang diperoleh petani untuk setiap satuan biaya yang dikeluarkan dalam kegiatan usahatani. Nilai $\mathrm{R} / \mathrm{C}$ rasio yang dihasilkan dapat bernilai lebih satu atau kurang dari satu. Apabila nilai $\mathrm{R} / \mathrm{C}$ lebih dari satu maka penerimaan yang diperoleh lebih besar dari unit biaya yang dikeluarkan untuk memperoleh penerimaan tersebut, sementara itu apabila nilai R/C kurang dari satu menunjukkan bahwa tiap unit biaya yang dikeluarkan akan lebih besar dari penerimaan yang diperoleh. Apabila R/C sama dengan satu maka penerimaan yang diperoleh sama besarnya dengan biaya yang dikeluarkan untuk memperoleh penerimaan tersebut. Pada dasarnya semakin besar nilai $\mathrm{R} / \mathrm{C}$ rasio yang didapat menggambarkan semakin besarnya penerimaan usahatani yang diperoleh untuk setiap satuan biaya yang dikeluarkan.

\section{Konsep Return to Labor dan Return to Capital}

Menurut Soekartawi et al. (1984) imbalan kepada tenaga kerja dan imbalan kepada modal merupakan patokan yang baik untuk mengukur penampilan usahatani. Imbalan merupakan keberhasilan pengelolaan usahatani secara menyeluruh, maka untuk mengukur keberhasilan pengelolaan usahatani secara parsial (per bagian) perlu dihitung imbalan bagi faktor-faktor produksi yaitu imbalan bagi tenaga kerja (return to labor) dan imbalan bagi modal (return to capital).

Kamiliah (2009) menyatakan bahwa sebagai pemilik tenaga kerja yang telah dicurahkan dalam usahatani, petani seharusnya menerima imbalan sekurangkurangnya sama besarnya dengan upah seandainya petani tadi bekerja pada usahatani milik petani lain. Begitu pula bila sebagai pemilik modal, seharusnya petani menerima sejumlah jasa atau 
bunga yang sekurang-kurangnya sama besarnya dengan kalau dana modal tersebut disimpannya di bank. Jika imbalan bagi tenaga kerja dan modal lebih tinggi daripada biaya imbangannya, berarti secara ekonomis usahatani menguntungkan karena mampu memberikan imbalan yang wajar bagi faktorfaktor produksi dalam suatu usahatani.

\section{METODE PENELITIAN}

Penelitian ini dilakukan di Desa Ciaruteun Ilir,Kecamatan Cibungbulang, Kabupaten Bogor, Provinsi Jawa Barat. Desa ini merupakan salah satu sentra penanaman bayam yang sejak tahun 2007 mengalami perubahan peruntukkan lahan secara besar-besaran dari lahan sawah menjadi lahan kering untuk jenis komoditas sayuran terutama sayuran bayam (Program Kajian Agraria IPB 2012). Pelaksanaan pengambilan data dilakukan pada bulan Maret 2014. Data yang digunakan dalam penelitian ini adalah data primer dan data sekunder baik yang bersifat kualitatif maupun kuantitatif. Metode pengumpulan data dilakukan melalui survey dan wawancara langsung kepada petani. Bayam yang dihasilkan petani dihitung dalam satuan ikat gabung yang dikonversi menjadi satuan kilogram (satu ikat gabung $=100$ ikat kecil) dengan jumlah rata-rata di tingkat petani sebesar tujuh kilogram per ikat gabung. Tanaman bayam dapat dipanen pada umur 20-22 HST (Hari Setelah Tanam) pada musim kemarau (September-Oktober 2013) dan umur 30-45 HST pada musim hujan (Februari-Maret 2014).

Petani bayam di Desa Ciaruteun Ilir berdasarkan informasi yang didapat dari desa dibagi menjadi dua kelompok berdasarkan luasan lahan yang dimiliki petani yaitu petani lahan luas $(\geq 0.25 \mathrm{ha})$ dan petani lahan sempit $(<0.25$ ha $)$. Metode penarikan sampel dilakukan secara stratified sampling dengan teknik random sampling, yaitu sample diambil dari setiap sub-group atau strata yang terdapat dalam populasi yaitu menurut luas penguasaan lahan usahatani. Jumlah sampel untuk masing-masing kelompok petani (petani lahan luas dan petani lahan sempit) adalah 30 petani sehingga memenuhi kriteria sebaran normal.

Alat analisis yang digunakan adalah:

\section{Pendapatan Usahatani}

\section{Y tunai = penerimaan tunai $-B T U$ $Y$ total $=T R-B T O$}

\footnotetext{
Keterangan :

Y tunai : pendapatan tunai (Rp)

BTU : biaya tunai (Rp)

Y total : pendapatan total (Rp)

TR : penerimaan total $(\mathrm{Rp})$

BTO : biaya total (Rp)
}

\section{Analisis Imbangan Penerimaan dan Biaya ( $R / C$ Rasio)}

$$
\begin{aligned}
& R / C_{\text {tunai }}=\frac{\text { penerimaan total }}{\text { biaya tunai }} \\
& R / C_{\text {total }}=\frac{\text { penerimaan total }}{\text { biaya total }}
\end{aligned}
$$

Keterangan :

$\mathrm{R}$ : Revenue/ penerimaan $(\mathrm{Rp})$

$\mathrm{C}:$ Cost/pengeluaran (Rp)

Jika $R / C>1$ maka kegiatan usahatani efisien untuk dijalankan.

\section{Return to (Family) Labor dan Return to Capital Usahatani Bayam \\ Return to Labor $=$ penerimaan tunai-biaya tunai non TKLK jumlah HOK TKLK}


Return to Capital $=$

$\frac{\text { penerimaan total-biaya tunai-biya TKDK }}{\text { biaya total }} \times 100 \%$

Keterangan :

TKLK : tenaga kerja luar keluarga

TKDK : tenaga kerja dalam keluarga

\section{GAMBARAN UMUM LOKASI PENELITIAN}

\section{Karakteristik Petani}

Petani responden dalam penelitian ini dibagi menjadi beberapa karakteristik. Karakteristik tersebut perlu diketahui karena dapat mempengaruhi keberhasilan usahatani. Berdasarkan luas lahan, ratarata luas lahan petani sempit adalah 0.15 hektar sedangkan petani luas adalah 0.43 hektar. Mayoritas petani responden menjadikan pekerjaan usahatani bayam sebagai mata pencaharian utama. Lahan yang dimiliki petani pada umumnya merupakan milik sendiri. Berdasarkan golongan usia, petani berada pada usia produktif yaitu usia 31- 40 tahun yaitu sebesar 36.67 persen untuk petani sempit dan 41.67 persen untuk petani luas. Mayoritas tingkat pendidikan petani adalah tamatan SD dengan rata-rata pengalaman bertani selama 15-17 tahun dan jumlah tanggungan keluarga petani berada pada jumlah 3-4 orang.

\section{HASIL DAN PEMBAHASAN Penggunaan Sarana Produksi}

Beberapa faktor produksi yang dibutuhkan pada usahatani bayam meliputi benih, pupuk, obat kimia, tenaga kerja, lahan, dan alat-alat pertanian (berupa cangkul, kored, tahang, headsprayer, dan keranjang). Petani responden membutuhkan benih yang lebih banyak pada musim kemarau dibandingkan musim hujan (Tabel 1). Jumlah penggunaan pupuk pada usahatani luas relatif lebih banyak dibandingkan usahatani sempit. Hal ini

Tabel 1. Kebutuhan Faktor Produksi Pada Usahatani Bayam Menurut Klasifikasi Luas Lahan dan Musim di Desa Ciaruteun Ilir Periode Tanam Tahun 2013-2014

\begin{tabular}{|c|c|c|c|c|c|}
\hline \multirow{2}{*}{ Uraian } & \multirow{2}{*}{ Satuan } & \multicolumn{2}{|c|}{ Usahatani sempit } & \multicolumn{2}{|c|}{ Usahatani luas } \\
\hline & & MK & MH & MK & MH \\
\hline Benih bayam & $\mathrm{Kg} / \mathrm{ha}$ & 14.19 & 13.49 & 18.55 & 18.19 \\
\hline \multicolumn{6}{|l|}{ Pupuk } \\
\hline Urea & $\mathrm{Kg} / \mathrm{ha}$ & 167.03 & 140.19 & 60.40 & 118.60 \\
\hline TSP & $\mathrm{Kg} / \mathrm{ha}$ & 18.74 & 8.1 & 42.92 & 33.23 \\
\hline Phonska & $\mathrm{Kg} / \mathrm{ha}$ & 7.12 & 3.39 & 31.62 & 18.90 \\
\hline Kandang(ayam) & $\mathrm{Kg} / \mathrm{ha}$ & 5136.76 & 5063.70 & 7257.09 & 7457.37 \\
\hline Pestisida Curacron 500EC & $\mathrm{ml} / \mathrm{ha}$ & 511.88 & 525.68 & 291.74 & 404.15 \\
\hline \multicolumn{6}{|l|}{ Herbisida } \\
\hline Gramoxone 276SL & $\mathrm{ml} / \mathrm{ha}$ & 340.28 & 83.33 & & \\
\hline Roundup 486SL & $\mathrm{ml} / \mathrm{ha}$ & 0 & 100.00 & 220.83 & \\
\hline TKLK & $\mathrm{HOK} / \mathrm{ha}$ & 49.15 & 39.37 & 76.58 & 1107.89 \\
\hline TKDK & $\mathrm{HOK} / \mathrm{ha}$ & 64.04 & 57.57 & 34.21 & 28.64 \\
\hline
\end{tabular}


menunjukkan bahwa usahatani luas cenderung lebih intensif dalam pemberian pupuk daripada usahatani sempit. Kebutuhan pupuk yang paling tinggi adalah pupuk kandang (ayam) dibandingkan pupuk kimia karena pupuk ini merupakan pupuk dasar yang selalu digunakan pada awal penanaman sayuran bayam dan banyak mengandung unsur organik yang dibutuhkan di dalam tanah.

Jenis pestisida yang dipakai yaitu Curacron 500EC dan dua jenis herbisida yaitu Gramoxone 276SL dan Roundup 486SL. Tabel 1 menunjukkan bahwa penggunaan pestisida pada usahatani sempit lebih tinggi daripada usahatani luas. Hal ini menunjukkan bahwa petani pada usahatani sempit lebih intensif dalam penggunaan pestisida dibandingkan usahatani luas. Namun dalam penggunaan herbisida, petani luas lebih intensif daripada petani sempit karena penggunaan herbisida lebih tinggi pada petani luas.

Faktor produksi lain yang tak kalah penting yaitu tenaga kerja. Usahatani lahan sempit lebih intensif dalam penggunaan tenaga kerja dalam keluarga (TKDK) berupa kegiatan pengairan, sedangkan usahatani lahan luas lebih intensif dalam penggunaan tenaga kerja luar keluarga (TKLK) berupa kegiatan pemanenan dan pengairan.

\section{Analisis Pendapatan Petani Bayam}

Indikator yang digunakan untuk melihat keberhasilan usahatani yaitu analisis pendapatan dan $\mathrm{R} / \mathrm{C}$ rasio. Analisis pendapatan digunakan untuk mengetahui balas jasa terhadap faktor produksi yang digunakan petani. Analisis $\mathrm{R} / \mathrm{C}$ rasio digunakan untuk mengukur tingkat efisiensi usahatani dari segi biaya. Adapun analisis pendapatan petani bayam pada musim kemarau dan musim hujan yang mencakup penerimaan, biaya, pendapatan, dan $\mathrm{R} / \mathrm{C}$ yang diperoleh petani dapat dilihat pada Tabel 2. Penerimaan usahatani merupakan pendapatan kotor usahatani yang dibedakan menjadi penerimaan tunai dan penerimaan diperhitungkan. Jumlah bayam yang dipanen petani per hektar dan langsung dijual untuk usahatani sempit pada musim kemarau adalah 7 599.26 kilogram dan sebanyak 3292.34 kilogram pada musim hujan. Sementara itu, usahatani luas menghasilkan bayam sebanyak 9147.77 kilogram pada musim kemarau dan sebanyak 4035.07 kilogram pada musim hujan untuk setiap hektarnya.

Tabel 2 memperlihatkan penerimaan total per hektar usahatani sempit sebesar Rp18 668174 pada musim kemarau dan Rp21 112433 pada musim hujan, sedangkan usahatani luas sebesar Rp21 184253 pada musim kemarau dan Rp24 802574 pada musim hujan. Hal ini menunjukkan bahwa penerimaan usahatani luas lebih tinggi daripada usahatani sempit. Sementara itu, penerimaan total per hektar baik golongan petani responden lahan sempit maupun lahan luas pada musim hujan lebih tinggi dibandingkan pada musim kemarau. Hal tersebut dikarenakan harga jual bayam yang berlaku di pasar sangat tinggi pada musim hujan meskipun jumlah bayam yang diproduksi lebih rendah dibandingkan musim kemarau. 
Tabel 2. Analisis Pendapatan Usahatani Bayam (Kilogram) per Hektar di Desa Ciaruteun Ilir Periode Tanam Tahun 2013-2014

\begin{tabular}{|c|c|c|c|c|}
\hline \multirow[t]{2}{*}{ Uraian } & \multicolumn{2}{|c|}{ Usahatani sempit } & \multicolumn{2}{|c|}{ Usahatani luas } \\
\hline & MK & MH & MK & MH \\
\hline Penerimaan tunai & 18632776 & 21067546 & 21141884 & 24716807 \\
\hline Penerimaan non tunai & 35398 & 44887 & 42369 & 85767 \\
\hline Total penerimaan & 18668174 & 21112433 & 21184253 & 24802574 \\
\hline \multicolumn{5}{|l|}{ a. Biaya tunai } \\
\hline Benih bayam & 695685 & 698385 & 941448 & 926449 \\
\hline Pupuk kimia & 489466 & 381446 & 533236 & 421105 \\
\hline Pupuk kandang(ayam) & 1800334 & 1755152 & 2430296 & 2521409 \\
\hline Pestisida & 136160 & 138240 & 78706 & 107136 \\
\hline Herbisida & 26444 & 16750 & 89040 & 86653 \\
\hline Tali & 403666 & 266718 & 490627 & 277620 \\
\hline TKLK & 2218093 & 1750850 & 4082828 & 2944743 \\
\hline Biaya transportasi & 66667 & 66667 & 319206 & 315873 \\
\hline Sewa lahan & 535253 & 607183 & 584915 & 616860 \\
\hline Pajak lahan & 17125 & 18760 & 13814 & 16358 \\
\hline Total biaya tunai & 6388893 & 5700151 & 9564116 & 8234206 \\
\hline \multicolumn{5}{|l|}{ b. Biaya diperhitungkan } \\
\hline Sewa lahan (milik sendiri) & 804742 & 911884 & 630584 & 763600 \\
\hline TKDK & 3583117 & 3142790 & 1864042 & 1604067 \\
\hline Penyusutan pe & 598253 & 598253 & 383222 & 383222 \\
\hline Total biaya diperhitungkan & 4986112 & 4652927 & 2877848 & 2750889 \\
\hline Total biaya & 11375005 & 10353078 & 12441964 & 10985095 \\
\hline Pendapatan a & 12243883 & 15367395 & 11577768 & 16482601 \\
\hline Pendapatan atas biaya total & 7293169 & 10759355 & 8742289 & 13817479 \\
\hline $\mathrm{R} / \mathrm{C}$ Rasio atas biaya tunai & 3.24 & 4.21 & 2.43 & 3.27 \\
\hline $\mathrm{R} / \mathrm{C}$ Rasio atas biaya total & 1.67 & 2.09 & 1.74 & 2.32 \\
\hline
\end{tabular}

Keterangan: $\mathrm{MK}=$ Musim Kemarau, $\mathrm{MH}=$ Musim Hujan

Petani responden mampu menghasilkan 100 ikat gabung bayam (700 kilogram bayam) untuk satu kilogram benih bayam pada musim kemarau, namun hanya mampu menghasilkan 300600 ikat gabung pada musim hujan. Harga yang diteima petani pada musim kemarau yaitu Rp10 000- Rp20 000 per ikat gabung sedangkan pada musim hujan, petani menerima harga Rp40 000Rp70 000 per ikat gabung. Hal inilah yang menyebabkan penerimaan petani tinggi di muism hujan dibandingkan dengan musim kemarau.
Pendapatan yang diperoleh pada usahatani merupakan selisih dari penerimaan dengan biaya. Komponen biaya terbesar usahatani sempit baik pada musim kemarau maupun musim hujan adalah TKDK yaitu 31.50 persen dan 30.36 persen dari biaya total. Biaya TKDK usahatani sempit pada musim kemarau sebesar Rp3 $583 \quad 117$ dan sebesar Rp3 142790 pada musim hujan. Hal ini dikarenakan usahatani sempit lebih banyak menggunakan TKDK pada kegiatan usahatani bayam dibandingkan memperkerjakan buruh tani. 
Kegiatan yang membutuhkan banyak penggunaan TKDK usahatani sempit yaitu pengairan sebesar 36.28 HOK dan pengolahan lahan sebesar 10.61 HOK untuk musim kemarau, sementara itu penggunaan tenaga kerja untuk musim hujan pada pengairan sebesar 29.56 HOK dan pengolahan lahan sebesar 8.96 HOK. Penggunaan tenaga kerja pada musim kemarau lebih besar dibandingkan musim hujan karena petani di lokasi penelitian lebih intensif dalam melakukan proses pengairan, pemupukan, dan pemanenan.

Komponen biaya terbesar pada usahatani luas adalah biaya tenaga kerja luar keluarga (TKLK) baik untuk musim kemarau maupun musim hujan yaitu menyumbang sebesar 32.81 persen dan 26.81 persen terhadap biaya total. Biaya TKLK usahatani luas pada musim kemarau sebesar Rp4 $082 \quad 828$ dan sebesar Rp2 944743 pada musim hujan. Adanya keterbatasan sumberdaya yang dimiliki oleh tenaga kerja dalam keluarga membuat usahatani luas memerlukan banyak tenaga kerja luar atau buruh tani untuk mengelola lahan mereka.

Kegiatan yang membutuhkan TKLK paling besar pada usahatani luas adalah pemanenan sebesar 20.54 HOK untuk musim kemarau dan sebesar 15.69 HOK untuk musim hujan, kemudian diikuti oleh kegiatan pengairan. Hal ini dikarenakan usahatani luas di lokasi penelitian melakukan proses pemanenan yang lebih sering dibandingkan usahatani sempit dan memperkerjakan buruh tani tetap untuk melakukan proses pengairan.

Biaya TKLK yang dikeluarkan petani umumnya sebesar Rp 50.000 per hari untuk laki-laki dan Rp 30.000 per hari untuk tenaga kerja perempuan dengan standar jam kerja delapan jam. Tenaga kerja perempuan umumnya mengerjakan kegiatan panen dan penyiangan karena kegiatan lain dalam berusahatani dikerjakan sepenuhnya oleh tenaga kerja laki-laki. Adapun hal positif yang dapat dilihat pada usahatani luas di Desa Ciaruteun Ilir adalah petani sudah memiliki kemampuan ekonomi yang lebih baik dibandingkan usahatani sempit.

Pendapatan total petani yang tinggi pada musim hujan dibandingkan musim kemarau didukung oleh pengujian statistik menggunakan software SPSS yang menunjukkan bahwa terdapat perbedaan pendapatan total antara musim kemarau dengan musim hujan baik pada usahatani sempit (Lampiran 1) maupun usahatani luas (Lampiran 2).

Pengujian menggunakan uji t dengan taraf alpha lima persen menunjukkan hasil bahwa pendapatan pada usahatani sempit untuk musim kemarau dan musim penghujan diperoleh nilai p sebesar 0.008 persen. Angka ini lebih kecil dari nilai alpha, artinya pendapatan total petani bayam pada usahatani sempit antara musim kemarau dan musim hujan berbeda nyata. Begitu juga pada usahatani luas yang menghasilkan nilai $\mathrm{p}$ sebesar 0.002 persen yang berarti bahwa pendapatan total petani bayam pada usahatani luas antara musim kemarau dan musim hujan berbeda nyata. Kesimpulan yang didapatkan menunjukkan bahwa pendapatan petani baik lahan sempit dan luas memiliki pendapatan yang tinggi pada musim hujan dibandingkan musim kemarau. 
Tabel 3. Return to Family Labor dan Return to Capital Petani Sempit dan Petani Luas

\begin{tabular}{lrrrr}
\hline \multirow{2}{*}{ Uraian } & \multicolumn{2}{c}{ Usahatani sempit } & \multicolumn{2}{c}{ Usahatani luas } \\
\cline { 2 - 5 } & $\begin{array}{c}\text { Return to } \\
\text { family labor (Rp) }\end{array}$ & $\begin{array}{c}\text { Return to } \\
\text { capital (\%) }\end{array}$ & $\begin{array}{c}\text { Return to } \\
\text { family labor (Rp) }\end{array}$ & $\begin{array}{c}\text { Return to } \\
\text { capital (\%) }\end{array}$ \\
\hline MT Kemarau & & & & \\
Maksimal & 363846 & 149.23 & 5423185 & 213.88 \\
Minimal & 43586 & 22.73 & 76160 & 25.70 \\
Rata-rata & 174246 & 79.45 & 719565 & 82.32 \\
\hline MT Hujan & & & & \\
Maksimal & 770889 & 286.72 & 6850243 & 357.87 \\
Minimal & 62578 & 27.21 & $(51829)$ & $(9.47)$ \\
Rata-rata & 260257 & 124.36 & 1092997 & 142.69 \\
\hline
\end{tabular}

Hasil perhitungan $\mathrm{R} / \mathrm{C}$ rasio memperlihatkan bahwa penerimaan terhadap biaya pada usahatani luas lebih besar daripada usahatani sempit. Nilai rata-rata $\mathrm{R} / \mathrm{C}$ rasio usahatani sempit pada musim kemarau adalah 1.67 yang artinya dari setiap satu rupiah biaya yang dikorbankan petani sempit dapat menghasilkan penerimaan sebesar Rp 1.67 dan pada musim hujan adalah sebesar 2.09 yang artinya dari setiap satu rupiah biaya yang dikorbankan dapat menghasilkan penerimaan sebesar Rp 2.09. Hal ini juga terdapat pada petani luas dengan nilai $\mathrm{R} / \mathrm{C}$ rasio adalah 1.74 untuk musim kemarau dan 2.32 untuk musim hujan. Oleh karena itu petani luas lebih efisien dalam menjalankan usahatani bayam daripada petani sempit untuk setiap musim tanam.

\section{Return to Labor dan Return to Capital}

Perhitungan ini berguna untuk menilai imbalan investasi petani responden usahatani sempit dan luas pada musim kemarau dan musim hujan terhadap penggunaan tenaga kerja dan modal usahatani bayam. Hasil perhitungan return to family labor dan return to capital petani responden dapat dilihat pada Tabel 3.

Berdasarkan Tabel 3 dapat diketahui bahwa nilai rata-rata return to labor usahatani sempit dan usahatani luas pada musim kemarau dan musim hujan lebih tinggi daripada nilai upah rata-rata tenaga kerja di Desa Ciaruteun Ilir yaitu sebesar Rp50 000 per hari. Hal ini menunjukkan bahwa pilihan petani responden untuk melakukan usahatani bayam sudah tepat daripada menjadi buruh tani. Hasil perhitungan return to capital menunjukkan bahwa pilihan petani untuk menginvestasikan modalnya pada kegiatan usahatani bayam yang dilakukan sudah tepat. Hal ini dikarenakan nilai rata-rata return to capital yang diperoleh lebih besar dari nilai suku bunga pinjaman yang berlaku, yakni 13.53 persen (suku bunga kredit modal kerja BI, kuartal II 2014).

\section{SIMPULAN DAN SARAN}

\section{Simpulan}

Kesimpulan yang diperoleh dari penelitian ini yaitu : 
1. Pendapatan usahatani bayam di Desa Ciaruteun Ilir berdasarkan kondisi antar musim yaitu musim kemarau dan musim hujan sudah menguntungkan baik pada usahatani lahan sempit maupun usahatani lahan luas.

2. Usahatani bayam untuk lahan sempit dan luas pada musim kemarau dan musim hujan sudah efisien dari segi biaya. Namun efisiensi usahatani lahan luas lebih tinggi daripada usahatani lahan sempit dan usahatani bayam pada musim hujan lebih efisien.

3. Imbalan terhadap tenaga kerja (return to labor) dan imbalan terhadap modal (return to capital) menunjukkan bahwa pilihan petani lahan sempit dan petani lahan luas untuk membudidayakan tanaman bayam sudah tepat karena mampu menciptakan upah yang lebih tinggi daripada upah ratarata serta mampu menciptakan pengembalian modal yang lebih tinggi daripada suku bunga kredit yang berlaku.

\section{Saran}

Usahatani bayam di Desa Ciaruteun Ilir sudah menguntungkan bagi petani. Oleh karena itu, kegiatan usahatani bayam perlu dipertahankan petani agar tetap tercipta pendapatan yang tinggi dan tetap menjadi sumber pendapatan utama. Golongan petani responden baik lahan sempit maupun lahan luas seharusnya responsif terhadap musim tanam dari tanaman yang dibudidayakan seperti kondisi penanaman pada musim kemarau dan musim hujan. Produksi bayam yang tinggi pada musim kemarau menjadikan nilai jual bayam murah sehingga petani perlu melakukan upaya penciptaan nilai tambah berupa produk turunan bayam. Sementara itu, pada musim hujan produksi bayam menurun namun harga jual bayam tinggi sehingga petani perlu intensif dalam merawat tanamannya. Upaya yang dilakukan bisa berupa pembuatan tudung plastik untuk melindungi tanaman dari serangan hama dan penyakit.

\section{DAFTAR PUSTAKA}

Abu O, Asember DJ. 2011. Opportunities for smallholder spinach farmers in Nigeria: a profit efficiency analysis. Economics Journal. 2(2): 75-79.

Adebisi-Adelani O, Olajide-Taiwo FB, Adeoye IB, Olajide-Taiwo LO. 2011. Analysis of production constraints facing fadama vegetable farmers in Oyo State, Nigeria. World Journal of Agricultural Sciences. 7(2): 189192.

Aldila HF. 2013. Analisis faktor-faktor yang mempengaruhi risiko produksi jagung manis (Zea mays saccharata) di desa Gunung Malang Kecamatan Tenjolaya Kabupaten Bogor. [skripsi]. Bogor (ID): Fakultas Ekonomi dan Manajemen. Institut Pertanian Bogor.

Badan Pusat Statistik. 2013. Luas panen, produksi, dan produktivitas sayuran di Indonesia tahun 2012. [internet]. [diunduh 23 Januari 2014]. Tersedia pada: www.bps.go.id 


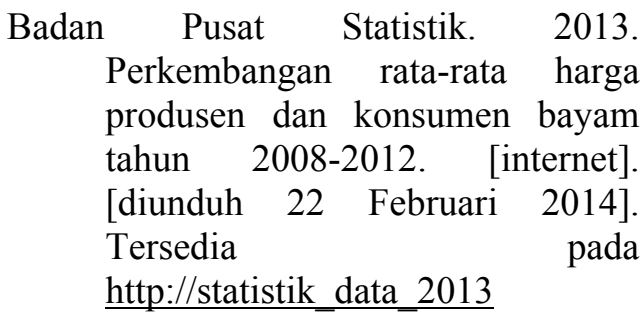

Dinas Pertanian Tanaman Pangan Provinsi Jawa Barat. 2012. Produksi sayuran menurut kabupaten komoditi : Bayam. [internet]. [diunduh tanggal 23 Januari 2014]. Tersedia pada: http://diperta.jabarprov.go.id/inde x.php/subMenu/924

Direktorat Jenderal Hortikultura. 2012. Rencana kinerja tahunan Direktorat Jenderal Hortikultura. Ditjen Hortikultura, Jakarta.

Hadisoeganda AWH. 1996. Bayam Sayuran Penyangga Petani di Indonesia (Monograf No 4, 1996). Balai Penelitian Tanaman Sayuran. Bandung.

Kamiliah W. 2009. Imbalan bagi faktorfaktor produksi pada usahatani sayuran di Desa Batulicin Irigasi Kabupaten Tanah Laut. JIPI. 16(3):191-194.

Lipsey RG, Courant PN, Purvis DD, Steiner PO. 1995. Pengantar Mikroekonomi Jilid 1. Wasana J, Kirbrandoko, penerjemah; Jakarta: Binarupa Aksara. Terjemahan dari: Economics 10th ed.

Pardede G. 2013. Hortindo ajak Belanda kembangkan hortikultura. [internet]. [diunduh 24 Januari 2014]. Tersedia pada www.antaranews.com.
Pemerintah Desa Ciaruteun Ilir. 2013.Laporan penyelenggaraan pemerintahan Desa Ciaruteun Ilir tahun 2013.

[PKA-IPB] Program Kajian Agraria Institut Pertanian Bogor. 2012. Perubahan peruntukkan lahan. [internet]. [diunduh 2015 Februari 3]. Tersedia pada: http://pka.ipb.ac.id/perubahanperuntukkan-lahan/

Rukmana R. 1994. Bayam Bertanam dan Pengolahan Pascapanen. Yogyakarta (ID): Kanisius.

Soekartawi. 2002. Analisis Usahatani. Jakarta (ID): UI-Press.

Soekartawi. 2005. Agroindustri dalam Perspektif Sosial Ekonomi. PT. Raja Grafindo. Jakarta.

Soekartawi, A Soeharjo, John L, Brian H. 1984. Ilmu Usahatani dan Penelitin untuk Pengembangan Petani Kecil. Jakarta (ID): UI - Pres.

Suratiyah K. 2009. Ilmu Usahatani. Jakarta (ID): Penebar Swadaya. 


\section{Lampiran 1. Hasil Uji Statistik Signifikansi Perbedaan Pendapatan Total Petani Bayam per Hektar Lahan Usahatani Sempit antara Musim Kemarau dan Musim Hujan}

\section{T-test}

Paired Samples Statistics

\begin{tabular}{|rr|r|r|r|r|}
\hline & & \multicolumn{1}{|c|}{ Mean } & N & \multicolumn{1}{c|}{ Std. Deviation } & \multicolumn{1}{c|}{ Std. Error Mean } \\
\hline Pair 1 & SEMPITK & 7293170,3667 & 30 & 4664607,96073 & 851637,00067 \\
& SEMPITH & 10759356,7667 & 30 & 7363009,80293 & 1344295,52007 \\
\hline
\end{tabular}

\section{Paired Samples Correlations}

\begin{tabular}{|c|c|c|c|c|}
\hline & & $\mathrm{N}$ & Correlation & Sig. \\
\hline Pair 1 & $\begin{array}{l}\text { SEMPITK \& } \\
\text { SEMPITH }\end{array}$ & 30 & ,466 & ,009 \\
\hline
\end{tabular}

\section{Paired Samples Test}

\begin{tabular}{|c|c|c|c|c|c|c|c|c|}
\hline & \multicolumn{5}{|c|}{ Paired Differences } & \multirow[t]{2}{*}{$\mathrm{t}$} & \multirow[t]{2}{*}{$\mathrm{df}$} & \multirow[t]{2}{*}{$\begin{array}{l}\text { Sig. (2- } \\
\text { tailed) }\end{array}$} \\
\hline & Mean & Std. Deviation & Std. Error Mean & $\begin{array}{r}95 \% \text { Confiden } \\
\text { the Diff }\end{array}$ & $\begin{array}{l}\text { ice Interval of } \\
\text { ference }\end{array}$ & & & \\
\hline & & & & Lower & Upper & & & \\
\hline $\begin{array}{c}\text { Pair } 1 \text { SEMPITK - } \\
\text { SEMPITH }\end{array}$ & $-3466186,4000$ & 6627960,36401 & 1210094,46721 & $-5941107,4741$ & $-991265,3259$ & $-2,864$ & 29 & 008 \\
\hline
\end{tabular}

H0 : $\mu$ sempitK $=\mu$ sempitH

H1 : $\mu$ sempitK $\neq \mu$ sempitH

Berdasarkan hasil uji-t di atas, diperoleh nilai-p (0.008) lebih kecil dari nilai alpha sebesar 5\%, maka tolak H0, artinya pendapatan total petani bayam pada usahatani sempit antara musim kemarau dan musim hujan berbeda nyata. 


\section{Lampiran 2. Hasil Uji Statistik Signifikansi Perbedaan Pendapatan Total Petani Bayam per Hektar Lahan pada Usahatani Luas antara Musim Kemarau dan Musim Hujan}

T-test

Paired Samples Statistics

\begin{tabular}{|lr|r|r|r|r|}
\hline & & & & \\
& & Mean & N & Std. Deviation & Std. Error Mean \\
\hline Pair & LUASK & 8742286,1667 & 30 & 6441708,68353 & 1176089,71828 \\
& & & & & \\
& LUASH & 13817478,1000 & 30 & 8759938,81953 & 1599338,69794 \\
\hline
\end{tabular}

Paired Samples Correlations

\begin{tabular}{|ll|r|r|r|}
\hline & N & Correlation & \multicolumn{1}{c|}{ Sig. } \\
\hline Pair 1 & $\begin{array}{l}\text { LUASK \& } \\
\text { LUASH }\end{array}$ & 30 &, 461 &, 010 \\
\hline
\end{tabular}

Paired Samples Test

\begin{tabular}{|c|c|c|c|c|c|c|c|c|}
\hline & \multicolumn{5}{|c|}{ Paired Differences } & $\mathrm{t}$ & $\mathrm{df}$ & $\begin{array}{l}\text { Sig. (2- } \\
\text { tailed) }\end{array}$ \\
\hline & \multirow[t]{2}{*}{ Mean } & \multirow[t]{2}{*}{ Std. Deviation } & \multirow[t]{2}{*}{ Std. Error Mean } & \multicolumn{2}{|c|}{$\begin{array}{l}95 \% \text { Confidence Interval of the } \\
\text { Difference }\end{array}$} & & & \\
\hline & & & & Lower & Upper & & & \\
\hline $\begin{aligned} \text { Pair } 1 & \text { LUASK - } \\
& \text { LUASH }\end{aligned}$ & $-5075191,9333$ & 8137455,23119 & 1485689,26360 & $-8113767,6543$ & $-2036616,2124$ & $-3,416$ & 29 & ,002 \\
\hline
\end{tabular}

$\mathrm{H} 0: \mu$ luasK $=\mu$ luasH

$\mathrm{H} 1: \mu$ luasK $\neq \mu$ luasH

Berdasarkan hasil uji-t di atas, diperoleh nilai-p (0.002) lebih kecil dari nilai alpha sebesar 5\%, maka tolak H0, artinya pendapatan total petani bayam pada usahatani luas antara musim kemarau dan musim hujan berbeda nyata. 